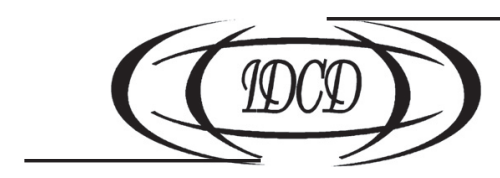

УДК 316.4:331.1

\author{
V.P. ZVONAR \\ $\mathrm{PhD}$ in Economics, senior researcher, \\ Ptoukha Institute for Demography and Social Studies \\ of the National Academy of Sciences of Ukraine, \\ 60 Taras Shevchenko blvd., Kiev, 01032, Ukraine \\ E-mail: ilovetea@mail.ru
}

\title{
REGULARITIES AND PRINCIPLES OF SOCIAL RESPONSIBILITY FORMATION IN LABOR RELATIONS
}

The paper deals with the theoretical problem of the development of regularities and principles of the formation of socially responsible behavior in the labor relations. The problem is induced from the conspicuous lack of scientific discourse on the theoretical consideration involving social responsibility as a phenomenon of labor economics and the relevant processes and the prerequisites for its formation. The paper suggests the structure of the regularities and principles of the formation of social responsibility in labor-related areas. The set of the regularities proposed includes the function specialization based on different risk perception, the meritocratic causation of statuses and roles and the coordination imperative due to interdependence of the labor agents. The regularities derive from the real convergence of partnership and paternalism and claim as the main non-linear dependencies in the structure of labor relations. They must be implemented in accordance with certain principles: solidarity, subsidiarity, freedom and trust. The regularities and principles specified are formulated on the grounds of identifying dialectical interpenetration and interaction of constructive and destructive types of labor relations.

Key words: social responsibility, labor relations, regularities, principles, agent.

\section{В.П. Звонар}

канд. екон. наук, старш. наук. співроб.

Інституту демографії та соціальних досліджень

ім. М.В. Птухи НАН України

E-mail: ilovetea@mail.ru

\section{ЗАКОНОМІРНОСТІ ТА ПРИНЦИПИ ФОРМУВАННЯ СОЦІАЛЬНОЇ ВІДПОВІДАЛЬНОСТІ В СФЕРІ ПРАЦІ}

Актуальність статті зумовлена недостатністю теоретичного обгрунтування в сучасному науковому дискурсі соціальної відповідальності як феномену економіки праці та вивчення процесу і передумов ї̈ формування. У статті розроблено і структуровано систему закономірностей і принципів формування соціально відповідальних відносин у сфері праці. Закономірностями формування соціальної відповідальності у сфері праці є спеціалізація функцій на основі різного сприйнятття ризику, меритократична зумовленість статусів і ролей, взаємозалежність сторін взаємодії та необхідність координації. Закономірності випливають із реального зближення суті партнерства і патерналізму та утверджують нелінійні залежності як основні у структурі соціально-трудових відносин. Вони реалізуються відповідно до визначених принципів: солідарності, субсидіарності, свободи і довіри. Систему вказаних закономір(c) ZVONAR V.P., 2014 
ностей і принципів сформульовано на основі виявлення діалектичного взаємопроникнення і взаємовпливу конструктивних та деструктивних видів соціально-трудових відносин.

Ключові слова: соціальна відповідальність, праця, відносини, закономірність, принцип, суб’єкт.

\title{
В.П. Звонар
}

канд. экон. наук, старш. науч. сотруд.

Института демографии и социальных исследований

им. М.В. Птухи НАН Украины

E-mail: ilovetea@mail.ru

\section{ЗАКОНОМЕРНОСТИ И ПРИНЦИПЫ ФОРМИРОВАНИЯ СОЦИАЛЬНОЙ ОТВЕТСТВЕННОСТИ В СФЕРЕ ТРУДА}

\begin{abstract}
Актуальность статьи обусловлена недостаточностью теоретического обоснования в современном научном дискурсе социальной ответственности как феномена экономики труда и изучения процесса и предпосылок ее формирования. В статье разработана и структурирована система закономерностей и принципов формирования социально ответственных отношений в сфере труда. Закономерностями формирования социальной ответственности в сфере труда являются специализация функций на основе различного восприятия риска, меритократическая обусловленность статусов и ролей, взаимозависимость сторон взаимодействия и необходимость координации. Закономерности вытекают из реального сближения сути партнерства и патернализма и утверждают нелинейные зависимости как основные в структуре социально-трудовых отношений. Они реализуются в соответствии с определенными принципами: солидарности, субсидиарности, свободы и доверия. Система указанных закономерностей и принципов сформулирована на основе выявления диалектического взаимопроникновения и взаимовлияния конструктивных и деструктивных видов социально-трудовых отношений.
\end{abstract}

Ключевые слова: социальная ответственность, труд, отношения, закономерность, принцип, субъект.

Introduction. The change of the priorities of the economic systems functioning, which continues today at the global, national and microeconomic levels, relates largely to the economic actualization of the theoretical and practical problem of social responsibility (SR). However, the formation of the methodological scope of SR as a socioeconomic phenomenon is ongoing. The regularities and principles of SR formation in socioeconomic relations are yet to be developed and analyzed. This is methodologically necessary for the construction of the economic theory of SR to be complete. At the same time, labor remains a central socioeconomic phenomenon. Therefore, without solving the problems in the labor relations (including those which are associated with SR formation) as a priority the success of solving the problems in any field of public life is questionable.

Studies conducted and solutions offered so far. Labor relations have been a major concern for many Ukrainian scientists. This includes papers of T. Zayats [1] and I.Teron [2] who have studied the theoretical and practical issues related to labor relations modernization in Ukraine. A. Kolot, O. Grishnova and V. Petiukh [3] dwelled on SR in employment policies. T. Grishina [4] thoroughly studied the management issues on SR in labor relations that could be of definite value for Ukraine. The experts of institutional economics are well known by the studies of the nature of opportunistic behavior, which could be considered as antipode of SR in economic interactions [5]. Nevertheless, there remains a conspicuous lack of scientific discourse on the theoretical consideration involving $\mathrm{SR}$ as a phenomenon of labor economics and the relevant processes and the prerequisites for its formation.

The paper's objective. The present paper aims to analyze and structure the basic regularities and principles of the formation of SR in labor relations. 
Ontology of the problem under consideration. The generalization of the scientific approaches to understanding of the philosophical category of SR gives the reasons to define it primarily as a characteristic of a social entity (an individual or a group). SR shows itself primarily in the ability of the entities to mutually agree on their actions and interests in the process of their activities. The social entities, vested with the ability of SR (the entities of SR), form the system of SR, the structure of which, in addition to the entities of SR, includes the subject matter of SR - something for which the entity is responsible - and the SR authorities - the social entities who estimate, control and regulate the activities of the entities of SR. Interrelations «the entities - the subject matters - the authorities» are caused by the social norms that signalize to the entity about the responsible behavior and the way of its influence on the subject matter of SR. SR entities, functionally divided into the real entities and the entities- authorities, are the living elements of SR system. Their existence determines the dynamics of the system [6]. The basic attribute that distinguishes them is a conscious, volitional and creative attitude to the social reality and also to the norms of SR, ensued from the joint creative work of the entities, and to the status of the authority, which has a conventional nature, and is determined and authorized by the entities themselves.

SR as a social system is involved in all kinds of social activities. Any social interaction can take SR characteristics. The economic interpretation of the nature of this interaction transforms its participants - social entities - into economic agents, and transforms social relations into the property relations that are the set of transactions. Thus, SR within the economic interaction comes out as a qualitative characteristic of the transaction process. SR of economic agents means the mutual abandonment of active or passive opportunistic practices. Opportunism is a direct denial of interests of a counterpart, and therefore is incompatible with socially responsible behavior.

The labor relations present a complex system of transactions with different opportunism risks. Labor transactions can be divided into «principal - agent» relations and network relations. The «principal - agent» relations are asymmetric in the terms of power. The employee - employer relations are known as «principal - agent» relations. The relationship between the labor entities and the government as a possible authority are also deemed as «principal - agent» relations. The network relations are relations among employees, as well as relations among employers. Relations of this type are symmetric in terms of power and could be perceived as cooperative or competitive. Cooperative relationship is a mutual exchange in the joint labor process. Competitive relationship may arise in a group of employers as buyers of labor or group of employees as sellers of labor or as buyers of workplace. The transaction here means a mutual agreement to observe competition rules.

SR in «principal - agent» relations means no abuse of existing information asymmetry and of power monopoly. In competitive relations, SR manifests as fair competition. In cooperative relations, SR means no «free-riding».

The regularities of SR formation in labor relations manifest the stable relations among the living elements of SR system in labor activity (the labor agents). The regularities taken together determine the essence of SR and the structure of SR system in labor relations, as well as characterize the process of reproduction of mutual non-opportunistic behavior of the agents. The first regularity of SR formation in labor relations is the specialization of the functions based on different risk perceptions. It is the case primarily for wage labor. Economic agents objectively differ by the ability to predict the course of events. Deciding on what and how to produce under conditions of uncertainty becomes so important that it requires the specialization for transactions participants. Because of this specialization and the fact of uncertainty, and there actually appears employment system [7]. Under conditions of un- 
certainty, SR assumes the recognizing of the systemic nature of the specialization indicated: both «risk-phile», and «risk-phobe» are an integral part of a single production mechanism with functions known for each.

The absolute ignoring of this regularity in the theory resulted in the appearance of the destructive concept of social antagonism by K. Marx. However, the main flaw in the theoretical model by K. Marx is not even that it denies the possibility of class peace, but that it ignores cause-and-effect relationship between enrichment (ownership of the means of production) and the peculiarities of individual traits, talents and knowledge of an economic agent. The second regularity of SR formation, namely the meritocratic causation of statuses and roles of socially responsible relations participants, is associated with the implementation of these peculiarities. The term «meritocracy» was first brought into use by M. Young, who has described and criticized the probable futuristic society with social status determined by the intelligence and the power positions occupied by the most talented individuals. The author described the inability of this system, which would certainly lead to usurpation of power by the intellectual elite [8]. Later, D. Bell proposed the positive meaning for the term «meritocracy» [9]. He constructed the political and sociological concept that emphasizes the importance of education not only in management, but also in social mobility. The author did not limit the interpretation of the term to intellectual aspects, defending the idea of «fair meritocracy» or high status because of individual achievements of a person. In this interpretation, the meritocratic system does not risk to become a dystopia of M. Young, contributing to the harmonious development of a person and society.

In socioeconomic relations meritocracy is generated by their inherent power asymmetry. The degree of this asymmetry is the criterion for differentiation between the traditional types of labor relations such as social partnership and paternalism. The projection of SR relations in labor activity is primarily social partnership relationship. SR in partnership must exist objectively, as the mutual harmonization of interests and activities of the agents is the foundation of partnership relations. Traditionally, science postulates partnership and paternalism as mutually opposite ways of organizing of labor relations. However, the theoretical analysis of their correlation reveals more complex liaison between them. Paternalism authorizes the existence of the dominant entity (the patron) in the field of social relations that limits the choice of other entities (client-entities). However, making a decision solely on behalf of client-entities, a patron does so in order to ensure their own well-being (displaying the care of them). This type of relationship pursues noble objectives, but clearly implies participants' asymmetry. The dominance of a patron has the meritocratic conditionality, but the paternalistic interference takes place against the will, the behavior models, and the values of client-entities.

The controversy of paternalistic practices is overcome within the concept of libertarian or «soft» paternalism: a patron, remaining essentially dominant, does not take away the right to choose from client-entities. His actions are aimed at ensuring the welfare of the latter (as in traditional paternalism), but he avoids direct coercion. His function is a «choice architecture»: to ensure the possibility of an independent selection of the most appropriate among courses of action by client-entities. The alternative to coercion is a grounded persuasion in favor of a particular choice, the demonstration of a smaller benefit of other options [10]. The theoretical basis for the appearance of libertarian paternalism is a criticism of the neoclassical model of «homo economicus». The main precondition for patron-client relations organization in libertarian way is a limited rationality of any economic agents. Its existence justifies patron intervention in the process of economic choice, but it should be moderate.

If the equality is called into question as an obligatory in partnership relations and the asymmetry is assumed in the partnership, then the latter becomes an apparent point of con- 
tact with the paternalism in the partnership structure. Such an assumption is fully justified, since the symmetry in the relations is not a basic principle of the partnership as opposed to the principle of entities reciprocity, recognition and acceptance of counterparts' interests. An absolute equality of partners is a scientific abstraction or even harmful, although stable, scientific myth [11].

Proceeding from the status of an employee defined by the subordination of his activities to the actions of employer during the goods production, an asymmetry in labor relations is axiomatic. In addition, it favors an employer as an entity, endowed with a greater propensity to risk, and therefore more willing to organize the production process. The meritocratic nature of patron status is obvious. The asymmetry is limited only by the scope of the statuses of an employer and an employee. They are naturally unequal as the participants in goods production process, because the contribution of each of them in the process is different. However, they are equal as the economic agents endowed with ownership rights. The asymmetry caused by paternalism, cannot mean arbitrariness of an employer. Paternalism is primarily the practice of a benevolent dominance, although it is associated with restriction of will of the recipient of this benevolence. It is benevolence (and hence the recognition of interests of client-entities by the patron, and in the majority of cases even patron's voluntary internalization of them) as a sign of the paternalistic relations that serves as a point of contact with the partnership in paternalism structure.

The asymmetry in labor relations has a pronounced conventional nature. So has the paternalism. The key moment here is not only the absence of coercion and the mutual benefit of the relationship, but also a mutual consent. With the consent of the entities one of them, willing and able to make better decisions, dominates. Namely, the consent is the first feature of the patron-client «partnership» transformation. However, faultlessness of the decisions of the patron is unguaranteed due to its limited rationality that characterized him as any economic agent. The patron has to take into account the knowledge and information, unknown to him, but available to the client-entities subordinated. For this reason, the socially responsible format of the paternalistic relationships provides the willingness of patron to acknowledge and to recognize the limits of his competence and the willingness of the client-entities to assist the patron. In this way, there is a reversing of the paternalistic relationship, and the bilateral communication appears on its basis as the second important feature of the patron-client «partnership».

The «hybridization» of partnership and paternalism asserts the nonlinear dependences as basic in the structure of SR relations in labor activity. The nonlinearity of the paternalistic relations appears maintaining the status of the participating entities and introducing the variability of their behavior rather than a single subordinated behavior. It also requires the bilateral interaction rather than the unilateral orientation of the actions of the patron and the inertia of the client-entity. This is the third regularity of SR formation in labor relations - an objective interdependence of the parties and the need for coordination.

In addition to social partnership and paternalism, the labor relations researchers also contradistinguish the constructive (solidarity, subsidiarity, competition) and the destructive (conflict and discrimination) types of the labor relations. In the context of SR issues, they might have a deeper meaning. Our further discourse will determine this meaning, and on this basis will clarify the basic principles of the formation of SR in labor relations. The analysis of them is methodologically necessary due to the need to examine the regularities and the principles in a single complex. The principle as the fundamental provision, premise determines the needs and requirements of SR formation process in labor relations in accordance with the given regularities. 
Some notions from the line above, especially solidarity and subsidiarity, can be considered namely as the principles of SR formation in labor relations. The partnership and nonlinear paternalism is impossible without solidarity of the participants.

The harmonization of the positions of partners inevitably results in convergence of these positions, which makes an agreement possible, and therefore manifests solidarity. The solidarity is one of the preconditions for the transformation of relations into the partnership. In the social philosophy the concept of «solidarity» captures the original internal unity of human existence in society, constitutes a social relationship between people in the form of small and large groups, based on mutual interest of people in each other, on their associations to reach their common objectives [12]. This principle is not confined to homogeneous groups (symmetric in terms of powers). According to the conventional sociological concept of E. Durkheim, the solidarity emerges in the system of the labor division, where each person performs the appropriate role [13]. Polemizing with the adepts of interclass antagonism, E. Durkheim argued that the class structure of society is provided by the labor division, which is socially necessary. Therefore, it forces the classes to work jointly. From these points, the relationships which are asymmetric in the terms of power - but are socially responsible - are also fully consistent with the principle of solidarity.

The inherent principle of SR formation in labor relations is also the subsidiarity, as the interaction between the partners is defined as the interaction between the autonomous entities.

The subsidiarity in cooperation is dictated by the reasoning of rationality and efficiency of solutions applied. It manifests in the fact that the entities resort to collective action upon the condition that such actions are more effective than individual efforts. The first who proposed the idea of the subsidiary was the medieval German philosopher J. Altuzius. The conceptual moment of his theory is the reflections on the proper interaction of any associations of people at different levels of social organization. Reflections of J. Altuzius became the basis for the formulation of the principle of subsidiarity, which first was disclosed consistently and holistically in the social doctrine of Catholicism in the early twentieth century. Philosophers of the Vatican postulated the subsidiarity as an important principle of social wisdom: it is unfair to take away the powers from people, which they are able to exercise on their own, and to transfer the powers to a community [14]. In the earlier philosophical works of the Vatican, the subsidiarity appears exactly as a call for harmonization of interests in the labor relations [15].

The competition in labor relations arises mainly in homogeneous groups - (in terms of power), in a group of employers as buyers of the labor force or in a group of employees as buyers of a workplace. At first glance, a competitive relationship in the labor relations is out of contract, because a transaction obliges to cooperate. However, it is clear that the agreement about competition rules, which can and should exist between the competing entities, is the result of the institutional transaction, and therefore it embodies a definite form of a contract. SR manifested in the competitive relationship as the practice of a fair competition. At the same time, it acquires the features of a controlled and productive competition.

A conflict is a complex multilevel open system of interactions based on the confrontation of the entities, which are opponents in the communication process. On the other hand, the conflict may precede the agreement of the interests of the entities. An indication of responsible relationship is not the absence of conflict itself, but the mutual benefit of its results for the participants. A conflict is a kind of competition to a certain extent. On this basis, the confrontation as a solution of the conflict in a non-partner way, but not conflict, should be understood as a destructive type of the labor relations. In SR system, a conflict ends successfully for all the parties due to the imperative of mutual benefit. Because the 
participants interact voluntarily, they must agree on the division of benefits received as a result of the transaction.

In our opinion, despite of its productive potential neither competition, nor conflict cannot be separate principles of SR formation. After all, this potential is realized primarily in free contact relations. It is freedom as the primary phenomenon concerning competition and as an independent principle of SR formation is the condition of the productive competition and mutually beneficial resolution of conflicts.

In SR system, a controversial phenomenon of discrimination is able to manifest positively. According to ILO, discrimination means any distinction, non-admission or preference, which results in nullifying or impairing equality of opportunity or treatment in the area of labor and occupation. Violation of rights, which consists the essence of discrimination, obviously makes impossible taking into account interests of entities discriminated. Therefore, their interests contradict the interests of entities discriminating and vice versa. Thus, the position of the discriminated excludes the probability of resolving the conflict in a mutually beneficial way. Therefore, it is clear that discrimination is a realized or an unrealized confrontation.

One of the tools, which eliminate the imbalance of interests of entities interacting, is the phenomenon of positive discrimination. This form of relationship, including the labor relationship, provides a resolution of the conflict in a responsible (partner) way. Nevertheless, we believe that discrimination - even positive one - also cannot be considered as separate principle of SR formation. It is «dissolved» in solidarity of the participants of labor relations, the mutual consent of which is a prerequisite for a positive effect of discrimination.

Trust rises as an essential principle of SR formation. The connection of SR and trust is objectified by the fact that the lack of trust is the root cause of information asymmetry, which in turn leads to opportunistic (irresponsible) behavior. The information symmetry and the reliability of transaction are impossible without trust. According to E. Ostrom, trust is an expectation of certain actions that affect the choiee of the individual when he has to take an action before actions of other individuals will be known [16].

P. Sztompka singled out the three ways of perception of the actions of people: hope, confidence and trust. Hope is passive, irrational expectation for better result. Confidence is passive, but focused and reasoned belief in a positive result. Trust is fundamentally different in that it is oriented «extrovertly» (outside of a trusting person) and it contains cognitive and behavioral components pronounced [17]. A certain level of trust is required to enter into any contract; it cannot be the result of bargaining, and is based on expectations formed as past experience. Of course, one could argue that if the contract is not fulfilled, the offender will be induced to its fulfillment by coercion of an authority. However, such coercion itself in fact has a contractual nature. Accordingly, one transaction is provided by another. The situation is a stalemate, if the performance of the last is as doubtful as of the first. That is why the trust as part of the contractual relationship is of principal importance.

At the same time, some authors exaggerate when they point at the antagonistic relationship of a contract and trust. According to their analysis, the formation of trust may indicate a displacement of contractual relations, and the emergence of the contract may indicate the destruction of trust. However, the contradistinguishing between a contract and trust is possible if the latter is interpreted narrowly as hope or confidence (by P. Sztompka), i.e. as irrational unreasonable expectation. And contract as the mutually agreed order of actions is impossible without trust as a justified mutual expectation in terms of the rationality. Contractual relations contain more trust than non-contract relations, because the actions of the parties to the agreement actually become predictable in the contractual relations. 
Conclusion. The becoming of the economic theory of SR involves analysis of regularities and principles of SR formation within the architectonics of labor relations. The set of the regularities proposed includes the function specialization based on different risk perception, the meritocratic causation of statuses and roles and the coordination imperative due to interdependence of the labor agents. The regularities arise from the real convergence of the essences of partnership and paternalism and affirm the nonlinear dependences as basic in the structure of the labor relations. They correlate with specific principles: solidarity, subsidiarity, freedom and confidence.

\section{LITERATURE}

1. Заяць T. А. Модернізація соціально-трудових відносин в цілях нарощування соціального капіталу / Т. А. Заяць // Наукові записки Національного університету «Острозька академія». Серія «Економіка». - 2011. - Вип. 16. - С. 277-283.

2. Терон I. В. Модернізація соціально-трудових відносин: сценарії, пріоритети, ефекти / І.В.Терон // Економічний часопис-XXI. - 2013. - № 7-8 (1). - С. 97-100.

3. Соціальна відповідальність: теорія і практика розвитку: [монографія / за ред. А. М. Колота]. K.: KHEУ, 2012. - $501 \mathrm{c}$.

4. Гришина Т.В. Социальная ответственность в системе современных социально-трудовых отношений / Т.В. Гришина. - М.: ИД «АТИСО», 2010. - 267 с.

5. Вільямсон O. Економічні інституції капіталізму : фірми, маркетинг, укладання контрактів / Олівер Е. Вільямсон ; пер. з англ. А. Олійник. - К. : АртЕк, 2001. - 457 с.

6. Парамонова И.М. Социальная ответственность: генезис, сущность, структура и стратегия развития (системный анализ): дис... канд. философ. наук: 09.00.11 / И.М. Парамонова. - СПб., 2001. $-126 \mathrm{c}$.

7. Найт Ф. Риск, неопределенность и прибыль / Ф. Найт. - М. : Дело, 2003. - С. 258-259.

8. Янг М. Возвышение меритократии / М. Янг // Утопия и утопическое сознание. - М. : Прогресс, 1991. - $241 \mathrm{c}$.

9. Белл Д. Грядущее постиндустриальное общество: опыт социального прогнозирования / Д. Белл. М. : Мысль, 1999. - 956 с.

10. Schlag P. Nudge. Choice Architecture and Libertarian Paternalism / P. Schlag // Michigan Law Review. 2009. - 108 : 913. - P. 913-924.

11. Масюк O. Міфологеми соціального партнерства / О. Масюк // Політичний менеджмент. 2008. - № 8. - С. 101-109.

12. Червяков А.А. Культура солидарности как феномен глобальной культуры / А.А. Червяков // Вестник Ставропольского государственного университета. - 2007. - № 50. - С. 269-276.

13. Дюркгейм Э. О разделении общественного труда / Э. Дюркгейм. - М. : Наука, 1992. - С. 57-58.

14. Quadragesimo Anno. (The Fortieth Years) On Reconstruction of the Social Order. - Encyclical of Pope Pius XI issued on May 15, 1931 [Електронний ресурc]. - Режим доступу: http://www.osjspm.org/ majordoc_quadragesimo_anno_officialtext.aspx

15. Renum Novarum. Encyclical of Pope Leo XIII on Capital and Labor [Електронний ресурс]. - Режим доступу: http://www.vatican.va/holy_father/leo_xiii/encyclicals/documents/hf_l-xiii_enc_15051891_rerum-novarum_en.html

16. Ostrom E.A. Behavioral Approach to the Rational Choice Theory of Collective Action / E.A. Ostrom // American Political Science Review. - 1998. - March. - 92, No. 1. - P.12.

17. Sztompka P. Trust: a Sociological Theory / P. Sztompka. - Cambridge : Cambridge University Press, 1999. - P. 25.

\section{REFERENCES}

1. Zayats', T. (2011) Modernizatsiya sotsial'no-trudovykh vidnosyn v tsilyakh naroshchuvannya sotsial'noho kapitalu [Modernization of labor relations for the purpose of social capital formation]. Naukovi zapysky Natsional'noho universytetu «Ostroz'ka akademiya». Seriya Ekonomika. - Scientific Proceedings of Ostrog Academy National University. Series Economics, 16, 277-283 [in Ukrainian]. 
2. Theron, I. (2013) Modernizatsiya sotsial'no-trudovykh vidnosyn: stsenariyi, priorytety, efekty [Modernization of socio-labor relations: scenarios, priorities and effects]. Ekonomichnyy chasopys-XXI-The Economic Annals-XXI Journal, 7-8 (1), 97-100 [in Ukrainian].

3. Kolot, A. (Ed.). (2011). Sotsia'na vidpovidal'nist': teoriia i praktyka rozvytku [Social Responsibility: Theory and Practice of development]. Kyiv: Hetman National Economic University [in Ukrainian].

4. Grishina, T.V. (2010). Social'naja otvetstvennost'v sisteme sovremennyh social'no-trudovyh otnoshenij [Social responsibility in the modern system of labor relations]. Moscow: ATISO [in Russian].

5. Williamson, O. (2001). Ekonomichni instytutsii kapitalizmu: firmy, marketynh, ukladannia kontraktiv [The economic institutions of capitalism: firms, marketing, contracting]. Kyiv: ArtEk [in Ukrainian].

6. Paramonova, I.M. (2001). Sotsial'naya otvetstvennost': genezis, sushchnost', struktura i strategiya razvitiya (sistemnyy analiz) [Social responsibility: genesis, nature, structure and strategy development (system analysis)]. Candidate's thesis. St. Petersburg [in Russian].

7. Knight, F. (2003). Risk, neopredelennost' i pribyl' [Risk, Uncertainty and Profit]. Moscow: Delo [in Russian].

8. Young, M. (1991). Vozvyshenie meritokrati [The Rise of the Meritocracy]. Moscow: Progress [in Russian].

9. Bell, D. (1999). Grjadushhee postindustrial'noe obshhestvo: Opyt social'nogo prognozirovanija [The coming of post-industrial society: A venture of social forecasting]. Moscow: Mysl' [in Russian].

10. Schlag, P. (2009). Nudge, Choice Architecture and Libertarian Paternalism. Michigan Law Review, 108, 913-924 [in English].

11. Masiuk, O. (2008). Mifolohemy sotsial'noho partnerstva [Myths of social partnership]. Politychnyj menedzhment - Political management, 8, 101-109 [in Ukrainian].

12. Chervjakov, A. (2007). Kul'tura solidarnosti kak fenomen global'noj kul'tury [Culture of solidarity as a phenomenon of global culture]. Vestnik Stavropol'skogo gosudarstvennogo universiteta - Stavropol State University Journal, 50, 269-276 [in Russian].

13. Durkheim, E. (1991). O razdelenii obshhestvennogo truda [The division of social labor]. Moscow: Nauka [in Russian].

14. Quadragesimo, Anno (The Fortieth Years) On Reconstruction of the Social Order. Encyclical of Pope Pius XI. Retrieved from: http://www.vatican.va/holy_father/pius_xi/encyclicals/documents/hf_pxi_enc_19310515_quadragesimo-anno_en.html [in English].

15. Renum Novarum. Encyclical of Pope Leo XIII on Capital and Labor. Retrieved from: http://www.vatican. va/holy_father/leo_xiii/encyclicals/documents/hf_l-xiii_enc_15051891_rerum-novarum_en.html [in English].

16. Ostrom, E. (1998). Behavioral Approach to the Rational Choice Theory of Collective Action. American Political Science Review, Vol. 92, 1, 12 [in English].

17. Sztompka, P. (1999). Trust: a Sociological Theory. Cambridge: Cambridge University press [in English].

Стаття надійшла до редакції журналу 28.07.2014 